\title{
Cytotoxicity of $\alpha$-terpineol in HeLa cell line and its effects to apoptosis and cell cycle
}

\author{
Rasuane Noor $^{1 *}$, Indwiani Astuti ${ }^{2}$, Mustofa ${ }^{2}$ \\ 1 Program Studi Pendidikan Biologi, Fakultas Ilmu Pendidikan, Universitas Muhammadiyah, \\ Metro \\ 2 Department of Pharmacology and Therapy, Faculty of Medicine, Universitas Gadjah \\ Mada, Yogyakarta
}

\begin{abstract}
$\alpha$-Terpineol is a natural compound of terpenoid alcohols class. However, it can be synthesized from $\alpha$-pinene of turpentin content. $\alpha$-Terpineol has been reported as potential anticancer agent due to its activity on inhibition of cells growth and induction of tumor cell death. However, its anticancer activity in HeLa cervical cancer cells line has never been studied, yet. The aim of this study was to evaluate the cytotoxicity of $\alpha$-terpineol and its effects to apoptosis and cell cycle. This was a quasi-experimental study with post-test only with non-equivalent control group design. Cytotoxicity of á-terpineol was evaluated using MTT cell viability assay. The effect of $\alpha$ terpineol on cell apoptotis was tested using acridine orange-ethidium bromide staining method, whereas its effect on cell cycle was evaluated by flowcytometry method. The results showed that $\alpha$-terpineol had cytotoxicity against HeLa cell with an $I_{50}$ value about $12.46 \mu \mathrm{g} / \mathrm{mL}$. Furthermore, $\alpha$-terpineol induced the HeLa with an $\mathrm{IC}_{50}$ value about $13.12 \mu \mathrm{g} / \mathrm{mL}$. Cell accumulation at $\mathrm{G} 1$ phase during cell cycle after incubation with $\alpha$-terpineol (52.78) was observed. In conclusion, $\alpha$-terpineol is potential as an anticancer due to its ability to induce cell apoptosis and to inhibit the cell cycle at $\mathrm{G} 1$ phase.
\end{abstract}

\section{ABSTRAK}

$\alpha$-Terpineol adalah senyawa bahan alam golongan alkohol terpenoid. Namun demikian senyawa ini telah berhasil disintesis dari $\alpha$-pinen dalam terpentin. $\alpha$-Terpineol dilaporkan sebagai antikanker potensial karena aktivitasnya dalam menghambat pertumbuhan sel dan menginduksi kematian sel tumor. Namun demikian, aktivitas antikankernya pada sel kanker serviks HeLa belum pernah diteliti. Tujuan penelitian ini adalah mengkaji sitotoksisitas $\alpha$-terpineol dan efeknya pada apoptosis dan siklus sel. Penelitian ini merupakan penelitian eksperimental kuasi dengan rancangan quasiexperimental study with post-test only with non-equivalent control group. Sitotoksisitas $\alpha-$ terpineol dikaji dengan penetapan viabilitas sel MTT. Efek $\alpha$-terpineol terhadap apoptosis sel diuji dengan metode pengecatan acridine orange-ethidium bromide, sedangkan efeknya pada siklus sel diuji dengan metode flowsitometri. Hasil penelitian menunjukkan $\alpha$-terpineol mempunyai sitotoksisitas melawan sel HeLa dengan nilai $I_{50}$ sekitar $13.12 \mu \mathrm{g} / \mathrm{mL}$. Akumulasi sel pada fase G1 selama siklus sel setelah inkubasi dengan $\alpha$-terpineol (52.78) dijumpai dalam penelitian. Dapat disimpulkan, $\alpha$-terpineol potensial sebagai antikanker karena efeknya dalam menginduksi apoptosis dan menghambat siklus sel pada fase G1.

Keywords: $\alpha$-terpineol - cytotoxicity - apoptosis - cell cycle - anti cancer - HeLa

\footnotetext{
* corresponding author: rasuanenoor@gmail.com
} 


\section{INTRODUCTION}

Cancer remains a major health problem in the world, both in developed and developing countries. World Health Oganization (WHO) and World Bank estimate that 12 millions people worldwide suffer from cancer annually and 7.6 millions of them died. ${ }^{1}$ The high incidence and mortality of cancer patients are currently due to low rate of the success of treatments. Various methods against the cancer have been developed including surgery, radiation, immunotherapy, and chemotherapy. However, the success rate of the methods is still low due to its disadvantages. ${ }^{2}$ This situation encourages the efforts to discover and develope anticancer that more effective and sensitive without serious side effects. $^{3}$

Various strategies have been conducted in the discovery of anticancer agents including isolating active compounds from natural materials. The compound that is currently widely studied and developed as an anticancer agent is terpenoids. ${ }^{4}$ One of terpenoids derived from natural ingredients is terpineol. Terpineol is produced by various plants such as eucalyptus (Melaleuca leucadendra), pine (Pinus sp.) and limes (Citrus aurantifolia). ${ }^{5}$ It also can be synthesized from $\alpha$-pinene of turpentine which is derived from extract of sap of pine trees (Pinus merkusii). ${ }^{6}$ Terpineol can be synthesized into $\alpha$-terpineol which is reported to have potential as anticancer agents. Synthesis of $\alpha$ terpineol from $P$. merkusii that was grown in Indonesia was successfully conducted by Budiman. $^{7}$

$\alpha$-Terpineol has been reported as a natural compound that has a potential anticancer activity. This compound has been reported to inhibit growth and induce tumor cell death by inhibiting the activity of NF-kB. ${ }^{8} \mathrm{NF}-\mathrm{kB}$ is a transcription factor that plays role in the regulation of gene expression of apoptosis, replication, tumorigenesis, inflammation and autoimmune diseases. NF-kB can be stimulated in the presence of growth factors, cytokines, lymphokines, radiation, pharmacologic agents, and stress. ${ }^{9}$

Cancer cell proliferation occurs beyond normal limits and it is uncontrolled. This is due to the disruption of cell cycle, the increase of angiogenesis and suppression of apoptosis. ${ }^{10}$ Apoptosis is a form of cell death designed to eliminate unwanted host cells. The process of apoptosis is programmed through a series of events involving a set of gene products. Apoptosis is responsible for physiological and pathological processes. In pathological process, apoptosis plays a major role in tumor cell death. ${ }^{11}$

A specific feature of apoptosis is hydrolysis process that involves some classes of caspase. Caspase triggers endonuclease activity which breaks nucleus and cytoskeletal proteins seen in apoptotic cells. The DNA of apoptotic cells shows a typical fraction size of $50-300 \mathrm{kbp}$. Furthermore, there is a degradation of internucleosomal DNA by endonucleases into oligonucleosome in various sizes between 120 $-200 \mathrm{bp}$. In agarose gel electrophoresis, they appear as fragments of DNA ladder. ${ }^{10,11}$

Cancer cells are capable of avoiding apoptosis. ${ }^{11}$ Activation of apoptosis, both in extrinsic and intrinsic pathways, will lead to activation of caspase- 3 as an executioner caspase. When caspase- 3 is activated, cell death (to commit suicide) or apoptosis is inevitable. Many new therapeutic methods were developed with the aim of spurring cancer cell apoptosis by activating apoptotic cascade. However, cancer cells that have variety of mutations can avoid this apoptotic cascade. ${ }^{12}$

HeLa cells are epithelial cells derived from cervical adenocarcinoma of humans infected with human papilloma virus (HPV) 18. The HPV 18 virus expresses two oncogenes, E6 and E7. 
The E6 protein binds to tumor suppressor proteins p53 which accelerates degradation, whereas the $\mathrm{E} 7$ protein binds to the active form of $\mathrm{Rb}$ family. This bond causes the destabilization of $\mathrm{Rb}$ and breaks the $\mathrm{Rb} / \mathrm{E} 2 \mathrm{~F}$ complexes that play role in suppressing transcription of genes required for cell cycle progression. ${ }^{13,14}$

The activity of $\alpha$-terpineol in cervical cancer cells (HeLa) has never been studied, yet. Therefore, this study was conducted to evaluate the cytotoxicity of $\alpha$-terpineol in HeLa cells. Furthermore, this study also aimed to examine whether the death of HeLa cells is caused by apoptotic process and how it affects the cell cycle.

\section{MATERIALS AND METHODS}

\section{Materials}

This was a quasi-experimental study using post-test only with non-equivalent control group design. This study was conducted on HeLa cells after incubated with $\alpha$-terpineol. The $\alpha$ terpineol was obtained and synthesized by Prof. Dr. ArifBudiman of the Department of Chemical Engineering, Universitas Gadjah Mada. HeLa cells were obtained from the Laboratory of Parasitology, Faculty of Medicine, Universitas Gadjah Mada.

\section{Cytotoxicity assay}

Cytotoxicity of $\alpha$-terpineol was evaluated on HeLa cell line using the MTT assay. ${ }^{15} \mathrm{HeLa}$ cells were distributed in 96-wells microplates at $1 \times 10^{4}$ cells per well in $100 \mathrm{~mL}$ and then 100 $\mathrm{mL}$ of complete RPMI 1640 medium were added. The cell cultures were then incubated in $5 \% \mathrm{CO}_{2}$ incubator at $37^{\circ} \mathrm{C}$ for 24 hours. Following after incubation, the medium was removed and replaced with new complete RPMI 1640 medium containing various concentrations of $\alpha$-terpineol ( 0.38 to $48.20 \mu \mathrm{g}$ ) $\mathrm{mL})$. The culture and $\alpha$-terpineol were then incubated again in $5 \% \mathrm{CO}_{2}$ incubator at $37^{\circ} \mathrm{C}$ for 24 hours. After the incubation, the medium was removed and the culture were added 100 $\mathrm{mL}$ of RPMI 1640 medium and $10 \mathrm{~mL}$ of MTT [3-9,4,5-dimethylthiazole-2-yl-2,5-diphenyltetrazolium bromide] reagent and then incubated for 4 hours. The reaction was stopped by adding $100 \mathrm{~mL}$ of $10 \%$ sodium dodecyl sulfate (SDS) in $0.01 \mathrm{~N} \mathrm{HCl}$. Microculture plates were then shaken gently for 5 minutes, covered with aluminium foil and incubated at room temperature for 12 hours. Absorbance of the microculture plates was measured in an ELISA plate reader at $\lambda 595 \mathrm{~nm}$. The percentage of inhibition of cell growth was obtained by this formula:

$\frac{(\text { Absorbance control - absorbance media })-(\text { absorbance of sample cells }- \text { absorbance media })}{(\text { absorbance control - absorbance media })} \times 100 \%$

Inhibitory Concentration $50 \%\left(\mathrm{IC}_{50}\right)$ i.e. concentration of $\alpha$-terpineol that inhibit $50 \%$ of cell growth was then determined by probit analysis. Doxorubicin was used as positive control in this study.

\section{Apoptotic assay}

Apoptosis assay was carried out by examining the morphology of HeLa cells which were incubated with $\alpha$-terpineol for 24 hours. ${ }^{16}$ The HeLa cells culture in complete RPMI 1640 medium at a final concentration of $5 \times 10^{4} / \mathrm{mL}$ were distributed in 24-wells plates coated with coverslip at the bottom. The cells were then treated with $1000 \mu \mathrm{L}$ of $\alpha$-terpineol at a concentration equivalent with the $1 / 2 \mathrm{IC}_{50}(6.23$ $\mu \mathrm{g} / \mathrm{mL}), \mathrm{IC}_{50}(12.46 \mu \mathrm{g} / \mathrm{mL})$ and $2 \times \mathrm{IC}_{50}(24.92$ $\mu \mathrm{g} / \mathrm{mL}$ ) values and incubated in $5 \% \mathrm{CO}_{2}$ 
incubator at $37^{\circ} \mathrm{C}$ for 24 hours. After incubation, the medium was removed and the cells were washed gently with PBS. Coverslip containing the treated cells were removed to glass object and then stained with $100 \mu \mathrm{L}$ of mixture of acridine orange-ethidium bromide in PBS solution. The cells were observed under a fluorescence microscope with magnification of 100-200x. The apoptotic cells would emit brown fluorescence and the viable cells would emit green fluorescence. The number of apoptotic cells was calculated in each 100 cells. The pro-apoptotic ability of $\alpha$-terpineol was expressed by $\mathrm{EC}_{50}$ which was determined by probit analysis. Doxorubicin was used as control.

\section{Cell cycle analysis}

Cells cycle analysis was performed using flowcytrometry. One thousand $\mu \mathrm{L}$ HeLa cell culture were distributed in 6-well plates at density of $5 \times 10^{5}$ cells per well and incubated in $5 \% \mathrm{CO}_{2}$ incubator at $37^{\circ} \mathrm{C}$ overnight. After overnight incubation, the cells culture were added $500 \mu \mathrm{L}$ of $\alpha$-terpineol at two different concentrations which were equivalent to the value of $1 / 2 \mathrm{IC}_{50}(3.12 \mu \mathrm{g} / \mathrm{mL})$ and $\mathrm{IC}_{50}(6.23$ $\mu \mathrm{g} / \mathrm{mL}$ ) and incubated in $5 \% \mathrm{CO}_{2}$ incubator at $37^{\circ} \mathrm{C}$ for 24 hours. After incubation, the cells were then collected, harvested and centrifuged. Cell pellets were washed twice with $500 \mu \mathrm{L}$ of cold PBS and then then incubated with $400 \mu \mathrm{L}$ of propidium iodide reagent at $37^{\circ} \mathrm{C}$ for 10 minutes and transferred to flowcytotube. The cells were immediately analyzed by FACS Calibur flowcytometer to evaluate cell cycle profile. Flowcytometry data were analyzed with Cell Quest program to evaluate the cells distribution in each phase of cell cycle and to evaluate polyploidy. The cell cycle inhibition was observed by comparing the cells distribution of treated and untreated cells.

\section{Statistical analysis}

Data were presented as the mean \pm standard deviation (SD). Statistical comparisons were performed using Student's $t$-test. The differences between groups were considered statistically significant if a $\mathrm{p}$ value of less than 0.05 .

\section{RESULTS}

The cell growth inhibition of HeLa cells after incubation with $\alpha$-terpineol or doxorubicin in various different concentrations is presented in TABLE 1. After incubation with $\alpha$-terpineol at concentration $0.38 \mu \mathrm{g} / \mathrm{mL}$, the cell growth inhibition percentage was $6.75 \%$ and the inhibition increased along with the increase of $\alpha$-terpineol concentration. In the highest concentration $(48.20 \mu \mathrm{g} / \mathrm{mL})$, the inhibition was $84.45 \%$. The smallest concentration of doxorubicin $(0.75 \mu \mathrm{g} / \mathrm{mL})$, the inhibition was $29.11 \%$, while the largest concentration (100 $\mu \mathrm{g} / \mathrm{mL}$ ), the inhibition was $91.61 \%$ of inhibition. The inhibition increased along with the increase of doxorubicin concentration. Furthermore, the cytotoxicity $\alpha$-terpineol $\left(\mathrm{IC}_{50}\right.$ value of $12.46 \pm$ $13.29 \mu \mathrm{g} / \mathrm{mL})$ was lower than doxorubicin $\left(\mathrm{IC}_{50}\right.$ value of $6.33 \pm 0.31 \mu \mathrm{g} / \mathrm{mL})(\mathrm{p}<0.05)$.

The effect of $\alpha$-terpineol on the apoptosis of HeLa cell was analyzed using acridine orange-ethidium bromide staining. The morphological observation after staining is presented in FIGURE 1. The apoptotic cells emited brown fluorescence, whereas the viable cells emited green fluorescence. The percentage of apoptotic $\mathrm{HeLa}$ cells after treatment with $\alpha$-terpineol is presented in TABLE 2. The apoptosis ability of HeLa cells after incubation with $\alpha$-terpineol was expressed in $\mathrm{EC}_{50}$. The $\mathrm{EC}_{50}$ value after $\alpha$ terpineol incubation $(13.12 \pm 7.24 \mu \mathrm{g} / \mathrm{mL})$ was significantly higher than after doxorubicin incubation $(5.90 \pm 1.25 \mu \mathrm{g} / \mathrm{mL})(\mathrm{p}<0.05)$. It was indicated that the effect of $\alpha$-terpineol in cell apoptotic induction was lower than doxorubicin. 
TABLE 1. The HeLa cell growth inhibition after 24 hours incubation with $\alpha$-terpineol or doxorubicin and its $\mathrm{IC}_{50}$ value

\begin{tabular}{cccc}
\hline Compound & $\begin{array}{c}\text { Concentration } \\
(\mu \mathrm{g} / \mathrm{mL})\end{array}$ & $\begin{array}{c}\text { Growth inhibition } \\
(\text { mean } \pm \mathrm{SD} \%)\end{array}$ & $\mathrm{IC}_{50}(\mu \mathrm{g} / \mathrm{mI})$ \\
\hline & 48.20 & $84.45 \pm 2.88$ & \\
24.10 & $51.44 \pm 5.10$ & \\
& 12.05 & $27.00 \pm 9.04$ & \\
$\alpha$-Terpineol & 6.02 & $46.98 \pm 1.31$ & $12.46 \pm 13.29$ \\
& 3.01 & $37.83 \pm 0.30$ & \\
& 1.50 & $23.26 \pm 2.42$ & \\
& 0.75 & $14.37 \pm 2.95$ & \\
& 0.38 & $6.75 \pm 4.44$ & \\
& 100.00 & $91.61 \pm 2.41$ & \\
& 50.00 & $82.37 \pm 1.73$ & \\
& 25.00 & $68.51 \pm 2.41$ & \\
& 12.50 & $56.92 \pm 3.76$ & \\
& 6.25 & $44.48 \pm 4.60$ & \\
& 3.13 & $39.76 \pm 1.42$ & \\
& 1.57 & $33.07 \pm 4.85$ & \\
& 0.75 & $29.11 \pm 2.01$ & \\
\hline
\end{tabular}

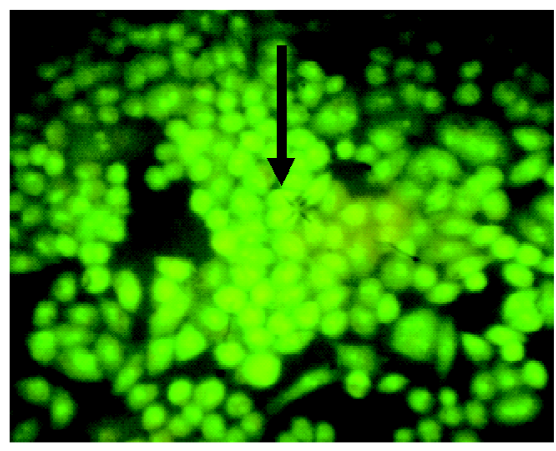

(a)

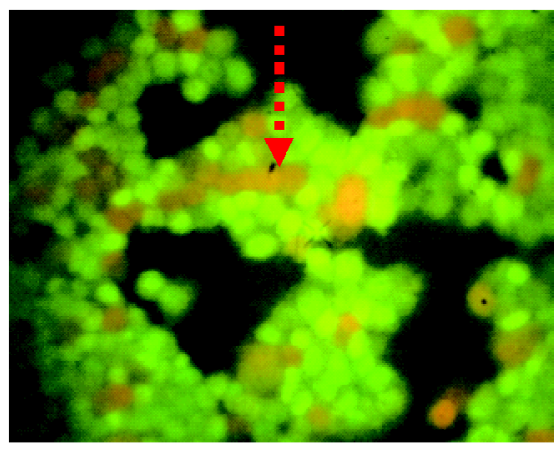

(b)

FIGURE 1. Morphological observation with ethidium bromide-acridin orange staining incubated of HeLa cells after incubation without (a) and with $\alpha$-terpineol (b). Viable cells emited brown fluorescence $(\downarrow)$ and apoptotic cells emited green fluorescence $(\downarrow)$. Observation was conducted using fluorescence microscope with magnification of 100x. 
TABLE 2. The percentage of apoptotic HeLa cells after treatment with $\alpha$ terpineol for 24 hours

\begin{tabular}{lccc}
\hline Treatments & $\begin{array}{c}\text { Concentration } \\
(\mu \mathrm{g} / \mathrm{mL})\end{array}$ & $\begin{array}{c}\text { \% apoptotic cells } \\
(\text { mean } \pm \mathrm{SD})\end{array}$ & $\mathrm{EC}_{50}(\mu \mathrm{g} / \mathrm{mL})$ \\
\hline Control & 0.00 & 0.00 & 0.00 \\
\multirow{2}{*}{$\alpha$-Terpineol } & 24.92 & $93.30 \pm 5.86$ & \\
& 12.46 & $36.00 \pm 7.55$ & $13.12 \pm 7.24$ \\
& 6.23 & $10.70 \pm 3.06$ & \\
Doxorubicin & 3.12 & $1.00 \pm 1.00$ & \\
& 6.33 & $56.33 \pm 13.80$ & $5.90 \pm 1.25$ \\
& 3.17 & $22.67 \pm 5.69$ & \\
\hline
\end{tabular}

TABLE 3 and FIGURE 2 showed the number of HeLa cells accumulation in each cell cycle after incubation with $\alpha$-terpineol. The incubation with $12.46 \mu \mathrm{g} / \mathrm{mL}$ of $\alpha$-terpineol showed that most of the cells were accumulated in sub G0/G1 phase, while incubation with 6.23 $\mu \mathrm{g} / \mathrm{mL}$ of $\alpha$-terpineol showed that most of the cells were in the G0/G1 phase. Incubation with doxorubicin also caused the cells to accumulate in sub G0/G1 phase. The high number of cells accumulation in sub G0/G1 phase was probably because most of the cells had undergone apoptosis.

TABLE 3. Average distribution of HeLa cells in each cell cycle after treatment with $\alpha$-terpineol for 24 hours

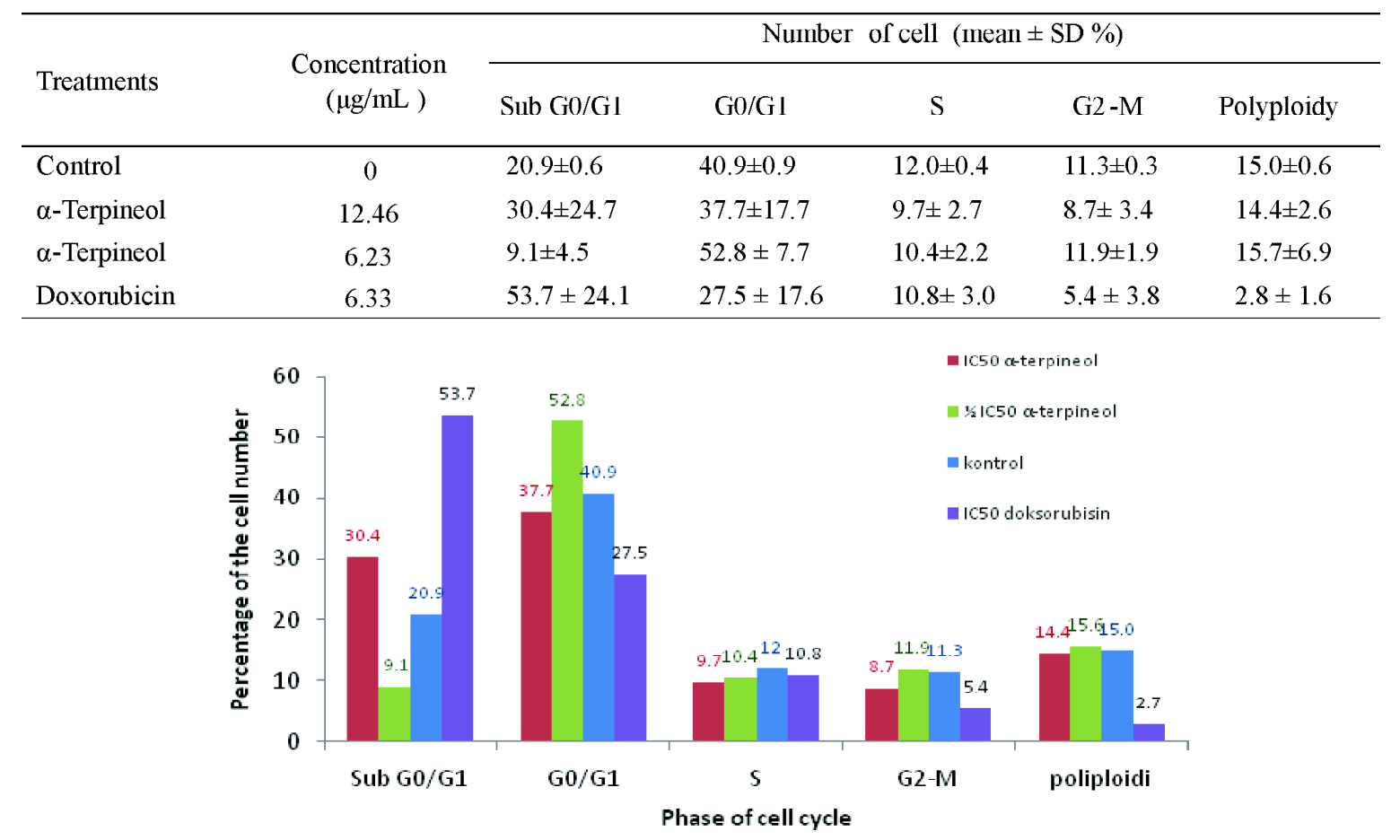

FIGURE 2. The distribution of HeLa cells in each cell cycle after incubation with $\alpha$-terpineol for 24 hours at concentration of 6.23 and 12.46 $\mu \mathrm{g} / \mathrm{mL}$ and with doxorubicin at concentration of $6.33 \mu \mathrm{g} / \mathrm{mL} /$ 


\section{DISCUSSION}

This study showed that $\alpha$-terpineol inhibited the HeLa cell growth in a dose-dependent manner with an $\mathrm{IC}_{50}$ value of $12.46 \mu \mathrm{g} / \mathrm{mL}$. America National Cancer Institute classifies a compound as a potential candidate for anticancer if it has $\mathrm{IC}_{50}$ value less than $30 \mu \mathrm{g} /$ $\mathrm{mL} .{ }^{17}$ Based on this criteria, $\alpha$-terpineol could be categorized as a potential anticancer compound. The $\alpha$-terpineol was less active than doxorubicin as positive control $\left(\mathrm{IC}_{50}: 5.90 \mu \mathrm{g} /\right.$ $\mathrm{mL}$ ) in this study. It may be caused the low purity of $\alpha$-terpineol $(51 \%)$ that tested. Therefore, development of synthesis process to obtain high purity will increase the cytotoxicity of $\alpha$ terpineol.

Studies concerning cytotoxicity of $\alpha$ terpineol in various cancer cell lines has been conducted by some authors. Hasan et al. ${ }^{8}$ reported that $\alpha$-terpineol was active against NCI-H69 lung cancer cell line. $\alpha$-Terpineol had also antiproliferative effects against erythroleukemic cell and TD47 breast cancer cell lines in vitro. ${ }^{18,19}$

The process of cell death through apoptosis was important as an indicator of $\alpha$-terpineol selectivity as a candidate of anticancer agent. The observation showed that all cells in control group were in green color which indicated that no cells death were observed in the control group. In contrast, incubation with $\alpha$-terpineol caused some cells to emit brown to red fluorescence which indicated the beginning of the loss of cell membrane permeability as an indicator of apoptosis. Then cell nuclei were fragmented and apoptotic bodies were formed. Incubation with $12.46 \mathrm{ig} / \mathrm{mL}$ of $\alpha$-terpineol for 24 hours can increase the number of apoptotic cells compared with control group.

This study showed that $\alpha$-terpineol and doxorubicin induced HeLa cells apoptosis. The $\mathrm{EC}_{50}$ value of $\alpha$-terpineol and doxorubicin were
13.12 and $5.90 \mu \mathrm{g} / \mathrm{mL}$, respectively. It is indicated that in these concentration, $\alpha$-terpineol and doxorubicin had caused $50 \%$ of HeLa cells apoptosis. The mechanism of apoptotic induction by doxorubicin is reported by stimulation of a p53-independent apoptosis through activating caspase- 3 in cancer cells. ${ }^{20}$

The ability to induce apoptosis of cancer cells is a fundamental starting point in the development of effective chemotherapeutic agents. The rate of apoptosis has a significant influence on the life span of normal and cancer cells. Modulation of apoptosis is very useful in the prevention and therapy of cancer. ${ }^{21}$ Selectivity has become an important point in the treatment of cancer. The process of cell death by apoptosis does not cause inflammation responses and can reduce side effects of the drugs in cancer patients. ${ }^{22}$ Expression of apoptosis regulatory protein is necessary to understand the molecular mechanism of apoptosis stimulation.

Cell cycle analysis showed that most of HeLa cells treated with $\alpha$-terpineol were accumulated in the G0/G1 phase. The highest number of cells (52.78\%) accumulated in G0/ G1 phase was reached with $\alpha$-terpineol concentration of $6.23 \mu \mathrm{g} / \mathrm{mL}$, whereas in the untreated control, the number of cell in the G0/ G1 phase was as much as $40.87 \%$. This illustrated that G0/G1 phase was the longest phase experienced by cells, and this is why the cells were accumulated on that phase. ${ }^{20}$

No significant difference on cell cycle was observed between $\alpha$-terpineol with concentrations of $6.23 \mu \mathrm{g} / \mathrm{mL}$ and $12.46 \mu \mathrm{g} / \mathrm{mL}$ with the control group. However, the data showed a trend of increasing accumulation of cell cycle in the G0/G1 phase in cells treated with 6.23 $\mu \mathrm{g} / \mathrm{mL}$ of $\alpha$-terpineol compared to controls. However, treatment with $12.46 \mathrm{ig} / \mathrm{mL}$ of áterpineol showed that most of the cells were accumulated in sub G0/G1 phase. Those results 
showed that treatment with $\alpha$-terpineol for 24 hours caused the cells to undergo apoptosis. Study in lymphoma cells U937-GTP showed that $\alpha$-terpineol induced the inhibition of cell cycle in G0/G1. That study reported that the number of cells in G0/G1 phase in treatment and control were $55 \%$ and $42 \%$, respectively. ${ }^{8}$

In HeLa cells, $\alpha$-terpineol inhibited TNF $\alpha$ and NF-kB translocation into cell nucleus. Inhibition of NF-kB activation can result in the reduction of cyclin $\mathrm{D}$ expression, an important protein in the induction of $\mathrm{G}$ phase of cell cycle. ${ }^{8,23}$ In MCF-7 cells, incubation with $\alpha$ terpineol for 6 hours had managed to regulate NF-kB which is associated with IL-1 $\beta$, IL1R1, IFNG, ITK, EGFR, AKT1S1, TNIK, TRlg FDD1, BAG1 and BAG3 genes. ${ }^{8}$ As a result, it is important to conduct further study on the influence of $\alpha$-terpineol isolated from pine tree sap in molecular level.

\section{CONCLUSION}

In conclusion, $\alpha$-terpineol is potential as an anticancer against HeLa cell through its ability to induce cell apoptosis and to inhibit the cell cycle at G1 phase. Further study will be conducted to evaluate the molecular mechanism of this compund as anticancer. Study its cytotoxicity on normal cell will be also conducted.

\section{ACKNOWLEDGEMENTS}

This study was funded by Ministry of Health, Republic of Indonesia through DIPA Risbin Iptekdok Research Grand 2011 with reference number of HK.03.05/1/393/2011. We would like to thank Prof. Ir. Arif Budiman, MS, D. Eng. from the Department of Chemical Engineering, Universitas Gadjah Mada for support the $\alpha$-terpineol.

\section{REFERENCES}

1. Anna M, Melanie W, Matt S, David, H. Cancerrelated beliefs and behaviours in eight geographic regions. Geneva: Union International Against Cancer (UICC), 2009.

2. Goldie JH. Drug resisten in cancer: a perspective. Cancer Metastasis Rev 2001; 20(1-2):63-8.

3. Hoffman EJ. Cancer and search for selective biochemical inhibitors. London: CRC Press Boca Raton, 1999.

4. Zhou YD, Kim YP, Mohammed KA, Jones DK, Muhammad I, Dunbar DC, et al. The terpenoid tetrahydroisoquinolone alkaloids emetine, klugine, and isocephaline inhibit the activation of hypoxia-inducible factor-1 (HIF-1) in breast tumor cells. J Nat Prod 2005; 68(6):947-50.

5. Anonym. The Merck Index. $11^{\text {th }}$ Ed. New Jersey: Merck \& Co. Rahway, 1989.

6. Aguirre-Roman M, De la Torre-Saenz L, Fores WA, Robau-Sanchez A, Elguezabal AA. Synthesis of terpineol from $\alpha$-pinene by homogeneous acid catalysis. Catalysis Today 2005; (107-108): 3104.

7. Budiman A. Sintesa senyawa antikanker terpentin dari hasil hutan non kayu (terpentin). Laporan Penelitian Intensif Ristek Jakarta: Perpustakaan Nasional, 2010.

8. Hassan SB, Gali-Muhtasib H, Goransson H, Larsson R. Alpha terpineol: a potential anticancer agent which acts through supressing NF-kappaB signalling. Anticancer Res 2010; 30(6):1911-19.

9. Kumar V, Abbas AK, Fausto N. Robbins and contran pathology basic of desease. $7^{\text {th }}$ Ed. Pennsylvania: Elsevier Saunders, 2005.

10. Besterman JM, Macleod AR. Targeting gene regulator for cancer therapy. Mod Drug Discov 2000; 51-58.

11. Hanahan D, Weinberg RA. The hallmark of cancer review. Cell 2000; 100(1):57-70.

12. Reed JC. Mechanisms of Apoptosis. Am J Pathol 2000; 157(5):1415-30.

13. Rahbari R, Sheahan T, Modes V, Collier P, Macfarlane C, Badge RM. A novel L1 retrotransposon marker for HeLa cell line identification. BioTechniques 2009; 46 (4): 277-84.

14. DeFillippis RA, Goodwin EC, Wu L, DiMaio D. Endogenous human papilloma virus E6 and E7 proteins differentially regulate proliferation, senescence, and apoptosis in hela cervical carcinoma cells. J Virol 2003; 77(2):1551-63. 
15. Wilson AP. Cytotoxicity and viability. In: Masters JRW editor. Animal cell culture: a practical approach. vol 1 (3rd ed.). Oxford: Oxford University Press, 2000.

16. Ribble D, Goldstein NB, Norris DA. Shellman YG. A simple technique for quantifying apoptosis in 96-well plates. BMC Biotechnol 2005; 5(12):17.

17. Suffness M, Pezzuto JM. Assays related to cancer drug discovery. In: Hostettmann K editor. Methods in plant biochemistry: assays for bioactivity, Vol. 6. London: Academic Press, London, 1990: 71133.

18. Anonim. Cancer treatment composition and method using natural plant essential oil. United States Patent US7 291650B2. 1998.

19. Indrasetiawan P, Astuti I, Mustofa. Activity of $\alpha$ terpineol as a potential anticancer candidate: cytotoxicity, proapoptotic and antiproliferative evaluation in TD47 cell lines. J Med Sci 2012; 44(1):10-7.
20. Cooper GM, Hausman RE. The cell: a molecular approach. Sunderland: MA American Society for Microbiology Press and Sinauer Associates, 2004.

21. Taraphdar AK, Roy M, Bhattacharya RK. Natural products as inducers of apoptosis: Implication for cancer therapy and prevention, Curr Sci 2001; 80(11): 1391 .

22. Gewies A. Introduction to apoptosis. Apo Review 2003; 3(1):1-26.

23. Shishodia S, Majumdar S, Banerjee S, Aggarwal BB. Ursolic acid inhibits nuclear factor-kappaB activation induced by carcinogenic agents through suppression of IkappaBalpha kinase and p65 phosphorylation: correlation with down-regulation of cyclooxygenase 2, matrix metalloproteinase 9, and cyclin D1. Cancer Res 2003; 63(15):437583 . 